\title{
FORDULÓPONTON A MAGYAR TERÜLETFEJLESZTÉSI POLITIKA, AVAGY SZEM ELÓL VESZÍTJÜK-E A FRANCIA MINTÁT?
}

\section{(Is Hungarian regional development policy at a turning-point, or are we losing sight of the French example?)}

\section{BARTA GYÖRGYI}

Magyarországon a tudatos területfejlesztési politika kidolgozásának kezdeteit az 1960-as évek elejére teszik. A területfejlesztési politika közel 30-éves korszakát a legszélsôségesebben értékelik; vannak, akik alapvetôen sikeresnek könyvelik el ezt a tevékenységet, mivelhogy elérte legfontosabb célját, a területi-gazdasági-társadalmi különbségek csökkentését. Mások kétségbevonják, hogy a területfejlesztési politikának bárminemû kihatása lett volna a gazdaságitársadalmi folyamatok térbeli alakulására, formálására. Az igazoló és elmarasztaló vélemények azonban azt nemigen vonják kétségbe, hogy az 1961-tốl 1989-ig tartó területfejlesztési politika a szocialista gazdasági rendszer produktuma volt, amely az általános szocialista és a sajátos magyar vonásokat egyaránt magán viselte, és éppen ezekkel a jellemvonásokkal magyarázhatók silkerei és kudarcai.

A francia területfejlesztési politika történetét tanulmányozva azonban kisérteties párhuzamokat lehet felfedezni a francia és a magyar törekvések között, és ezek a hasonlóságok korántsem vêletlenek. Franciaország településfejlesztési politikája már a kezdeti idốszakban is mintaképül szolgált Magyarország számára (ha ezt - politikai okokból - nem is hangoztatták a magyar területi szakemberek). A többi nyugat-európai országnál tradicionálisan centralizáltabb Franclaország — ahol a területfejlesztés valóban a kormánypolitika alkotó részévé vált, ahol a társadalom jobban elfogadta a hátrányos helyzetû́ területekkel való szolidaritás gondolatát, mint más országokban; és ahol a túlfejlett fôváros és a vidék konfliktusa alapvetô kérdés volt és maradt; - most méginkább a politikai rendszert változtató Magyarország ,, minta”-területévé, , ,referencla" országává válhat.

Önmagában is érdekes ezt a párhuzamos fejlôdést végigkövetni, bemutatva, hogy a hasonló erôfeszítések, célok, programok milyen eltérổ eredményt hoztak a különbözố politikai rendszerú és gazdasági fejlettségû́ országokban. A párhuzamos tendenciák, amelyek idóben kissé eltolva mutathatók ki, az 1970-es évek közepéig Franciaországban, és az 1980-as évek végéig Magyarországon, véget értek. Az új gazdasági körülmények elbizonytalanították és legyengítették a francia területfejlesztési politikát. A D.A.T.A.R. az elmúlt egy-két évben fogalmazta meg új területfejlesztési programját, válaszul az új kihívásokra, a megváltozott gazdasági-társadalmi-politikai körülményekre. A magyar területfejlesztési politika is megrendült, ideológiai alapja kétségessé vált, a társadalmi-gazdasági egyenlốtlenségek enyhítésére irányuló törekvése egyidốben vált rendkívül idôszerüvé és idôszerûtlenné, $\mathrm{s}$ a területfejlesztésre fordítható anyagi eszközök korlátozottabbak, mint valaha. Figyel-e megint a magyar területfejlesztési politika a francia gyakorlatra, amely kemény küzdelmet folytat haladó hagyományainak megốrzéséért, 
vagy szabadabb utat enged a spontán piaci folyamatok térformáló hatásainak? Ha másért nem, akkor ezért érdemes (újra) megismernünk a jelenlegi francia területfejlesztési törekvéseket.

\section{A francia területfejlesztési politika kezdetei 1950-tól 1963-ig}

Két alapvetổ térbeli konfliktus erósödött fel, és vált tarthatatlanná a XX. sz. közepén Franciaországban: a túlnövekedett Párizs és a vidék között (a francia népesség 1/6-a koncentrálódott Seine és Seine et Oise megyékbe, 100 évvel korábban csak 1/20-a élt itt; a század elsổ felében az ipari foglalkoztatottak száma $50 \%$-kal nổt a párizsi agglomerációban, míg az országos átlag csak 3\% volt; Párizsban koncentrálódott az 1950-es években a banki alkalmazottak 70\%-a, az üzleti forgalom $60 \%$-a, és a felsổoktatás $40 \%$-a), valamint a vidéki régiók között (a Le Havre-Marseille tengelytôl keletre az életszínvonal két-háromszorosa volt a tengelytôl NY-ra esố területekének). Ekkor fogalmazták meg az elsó átfogó területfejlesztési politikát, amelynek klasszikussá váló elemeit - a decentralizált iparfejlesztést, a mezôgazdaság modernizálását, a turizmus és az infrastruktúra fejlesztését, valamint a kultúra decentralizációját - minden olyan országban átvették és alkalmazták, ahol a terülefejlesztést figyelembe vették. 1954-55-ben iktatták törvénybe az elmaradott területek fejlesztésének szükségességét, amelyet két rendelkezés egészített ki: a párizsi régió további növekedésének adminisztratív megakadályozása (bizonyos mértéket meghaladó iparvállalat létesítését elôzetes engedélyhez kötötték, és 3 évre befagyasztották az engedélyek kiadását új irodák építésére és tudományos intézmények létesítésére), továbbá gazdaság- és területfejlesztési alap (Fonds de Développement Économique et Social) létrehozása az iparvállalatok áttelepítésére és a fejleszteni kívánt térségben létesítendô vállalatok költségeinek fedezésére. Erre az idốre datálható a 22 régió átfogó fejlesztési programjának kidolgozása.

Ez a területfejlesztési program nem volt túlságosan sikeres. A Párizsból kitelepített vállalatok igyekeztek a föváros $200 \mathrm{~km}$-es körzetében találni új telephelyet. A közigazgatási, de különösen a tudományos és oktatási, intézmények decentralizációjára tett kísérletek teljes kudarccal végződtek. (Olaszországban a Mezzogiorno fejlesztését az északi székhelyư nagyvállalatok részlegnyitásainak támogatásával próbálták elérni. A , részlegipar” letelepítése az elmaradott térségekben az olasz ipar- és területfejlesztési politika csốdjét jelentette.)

A magyar program ezeket a módszereket, intézkedéseket késốbb részben átvette, hibáiból, tévedéseibốl azonban sajnos nem okult. Elfogadta az ipar területi dekoncentrációját, a mezốgazdaság modernizálását, elhanyagolta viszont az infrastruktura fejlesztését és a kultúra decentralizálása csak jelszó maradt. A Budapest növekedésének megakadályozására hozott adminisztratív gazdasági rendszabályokat kiegészítették a betelepülés megszigorításával. A Településfejlesztési Alapot meglehetôsen későn, csak 1971-ben hozták létre, amely azonban jelentéktelen mértékủ volt, az ipari beruházásoknak a maga idejében mindössze 1\%-át tette ki, és az összes beruházásoknak csak 4-5\%-át orientálta. Néhány év elmúltával a területfejlesztési alap meg is szünt. A 60-as évek közepétól a VÁTI megyei fejlesztési terveket készített - hasonlóan a francia fejlesztés programjához.

A franciák - szerencséjükre - még a gazdasági prosperitás idôszakában vonták le következtetéseiket a területfejlesztés módszereinek és eszközrendszerének nem kellổ hatékonyságáról. 
Az 1960-as évek közepén még mód nyílt új, globális területfejlesztési akciók elindítására. A franciák tisztában voltak azzal, hogy átfogó decentralizálás nélkül semmiféle regionális fejlesztési program nem vezet eredményre. A hatalom decentralizálása a legnehezebb, a legkényesebb politikai harc, amelynek gyôzzelmét ốk is csak évtizedekkel késôbb ünnepelhették. A magyar viszonyok között a szocialista rendszerrel nem fért össze a decentralizációra való törekvés. A megyei tanácsok szerepe ugyan megnövekedett a 70-es évektốl kezdve, ezek azonban a központi akarat helyi végrehajtói voltak, önálló mozgásterük csekély volt. Az új gazdasági mechanizmus, amely a vállalatoknak ugyan jelentốs önállóságot biztosított, az intézményi struktúrát változatlanul hagyta. A gazdasági prosperitás időszakában, a 60-as, 70-es években, a termelés soha nem látott mértékben szóródott szét az országban, a termelés irányítása és ellenổrzése azonban területileg is egyre centralizáltabb lett.

Kiterjedt körzetekben, megyékben lett domináló a , részlegipar”, amely gyökértelen maradt, nem gerjesztett további fejlesztést a saját környezetében, helyzete gyorsan elbizonytalanodott a kevezốtlen közgazdasági környezetben. Nem véletlenül jellemezték ezt az iparosítási programot gyarmatosításnak. Budapest közigazgatási területén a lakosság számának növekedését, a gazdaság fizikai bôvülését sikerült ugyan megállítani, a Budapest körüli agglomerációs gyûrû́ azonban dinamikusan fejlődôtt, népsürüsége gyorsan növekedett.

\section{A területfejlesztés aranykora 1963-tól 1975-ig}

A franciák ezt az időszakot a területfejlesztés aranykorának nevezik, amely ideológiájában, célkitưzéseiben, eszközrendszerében és módszertanában átfogó és megalapozott politika volt, és meg is hozta a maga sikereit.

\section{A területfejlesztési politika ideológiája}

A területfejlesztési politika elóször az igazságtalannak tartott területi-társadalmi különbségek kiegyenlítését, de legalábbis csökkenését tekintette feladatának. Az 1960-as években már nemcsak szociális, de gazdasági jelentôséget is tulajdonítottak a területfejlesztésnek arra hivatkozva, hogy a területek, térségek közötti jelentôs gazdasági, fejlettségbeli különbségek az ország fejlôdését is lassítják. Ezt a logikusnak tetszố érvet azonban nagyon nehéz bizonyítani. Magyarországon is hosszú idôn át polémia folyt arról, vajon össze lehet-e egyeztetni a térbeli kíegyenlítési törekvéseket a gazdaságosság kritériumával. Azt ugyanis könnyen igazolni lehet, hogy különbözô környezetben végrehajtott beruházások milyen közvetlen eredménnyel térülnek meg (ez többnyire a fejlett területeknek kedvezett), azt viszont rendkívül nehéz nyomon kỏvetni, hogy bizonyos beruházások áttételesen és hosszútávon milyen fejlődést generálnak, nem beszélve a térbeli különbségek csökkentéséból adódó pozitív hatásokról.

\section{Közigazgatási reform - regionális reform}

A regionális politika sikeréhez vezetó fontos lépés volt a közigazgatási reform. Nyilvánvaló volt ugyanis, hogy az elózố idốszak törekvéseit elsôsorban az érintetlenül hagyott közigazgatási szervezet akadályozta. Országos szinten szembekerültek bizonyos ágazati minisztériumi programok (például a lakásépítés, vagy a gazdasági termelés programjai) a területfejlesztési cé$10 \mathrm{kkal}$. 
E konfliktusok rendezésére hozták létre 1963-ban a D.A.T.A.R-t (Délégation à l'Aménagement du Territoire et à l'Action Régional), a területfejlesztéssel foglalkozó, minisztériumi szintű intézményt. A D.A.T.A.R. fố feladata a területfejlesztési politika kidolgozása és összehangolása az ágazati programokkal.

Regionális szinten létrehozták a területfejlesztés 22 régióját, a területfejlesztés körzeteit. A kormány regionális szervezeteinek, a prefektusoknak, a kezében volt a döntéshozás joga, a regionális gazdaságfejlesztési bizottságok, a regionális közgyủlés elődjei, csupán konzultatív hatáskörökkel rendelkeztek. Mindemellett ez utóbbi intézmény már hozzájárult a régió gondjaival azonosuló, felelősségteljes gondolkodásmód kialakulásához.

A közigazgatás decentralizálásáért folytatott küzdelem végül a regionális reform kompromisszumát hozta 1972-ben. A regionális reform ugyan kibővítette a regionális közgyülés, az ún. regionális tanács hatáskörét, a valódi hatalmat azonban továbbra is a kormány helyi szervei, a prefektusok birtokolták. Végülis a közigazgatási reform csak 1982-ben teljesedett ki, és megadta a területi közösségek (collectivité territoriale) rangját.

Magyarországon nem volt közigazgatási reform. Voltak ugyan gyenge kísérletek a régió szisztémájának bevezetésére, 5-7 regióba osztva a 19 megyét, de ezek a próbálkozások szükségszerûen kudarcba fulladtak, mivel a régiók semmiféle politikai és gazdasági önállósággal nem lettek felruházva.

\section{A területfejlesztés elméleti alapjai}

A növekedési pólus elmélete, illetve a polarizált fejlesztés diffúziójának gondolata Francois Perroux nevéhez füzódik. Ez az elmélet teremtette meg annak a területfejlesztési programnak az alapját, amely bizonyos ágazatokban és bizonyos településekben - külsô erőforrás segítségével - végrehajtott beruházásokból a fejlôdés automatikus szétterjedését várta.

A területfejlesztési programoknak tehát az a feladatuk, hogy kijelöljék a növekedési pólusokat, és a fejlôdést legjobban elôsegítố beruházásokkal indítsák el a kedvezố folyamatokat. Ezek az erốfeszítések idôvel meghozzák az egész térségben a maguk gyümölcseit.

A magyar területfejlesztő̉k nemigen firtatták a növekedési pólus elméleti helyességét, a ráépülổ területi gazdaságpolitika francia célkitüzéseit azonban kritika nélkül átvették.

\section{A francia területfejlesztési politika gazdasági programja}

A regionális politikát három fổ területre összpontositották:

- decentralizált iparosítási program, mindenekelổt az ország nyugati, kevésbé fejlett térségeiben;

- városi infrastruktúra megerôsítése;

- a falusi térségek fejlesztése, a hozzá szorosan kapcsolódó környezetvédelmi programmal.

\section{A decentralizált iparfejlesztés}

Kezdetben a Párizsból kitelepítendố vállalatokra koncentrálódott, késốbb a beruházásokra adott közvetlen támogatások, kezdemények rendszere (la prime d'équipement) új vállalatok alapítását ösztönözte a fejleszteni kívánt térségekben. 
Barta Györgyi: Fordulóponton a magyar területfejlesztési politika, avagy szem elöl veszítjük-e a francia mintát? Tér és Társadalom, 6. 1992. 1-2. 17-35. p.

TÉT $1992 \cdot 1-2$ Fordulóponton a magyar településfejlesztési politika... 21

A városi infrastrúktura fejlesztésére kidolgozták a három fokozatú városhierarchia rendszerét. A legmagasabb szinten álltak az ún. ellenpólus városok (métropoles d'équilibres), középszinten a közepes méretû́ városok (villes moyennes), míg az alsó szintet a falusi térség jelentette. Egyidốben született meg tehát az ellenpólus városfejlesztési programja a középvároshálózat fejlesztésével, amelyet ugyancsak ebben az időben egészített ki az új városok építési programja. Az új városokat már nemcsak az angol alvóvárosok mintájára tervezték a nagyvárosi túlzsúfoltság enyhítésére, hanem , komplex” városokat építettek Párizs, Rovan, Lille és Lyon környezetében.

A falusi térség leromlásához, válságához vezetett a tömeges méretũ elvándorlás. Az ekkoriban megfogalmazott programok elsősorban e térségek eltartó képességét voltak hivatva növelni, kiegészítve bizonyos, jobban veszélyeztetett speciális zónák (hegyvidéki területek, tengerparti térségek) környezetvédelmi programjaival (Langudoc-Roussillon, Durance völgy, Gascogne vidékének öntözési programja, a Langudoc-Aqvitain part védelme, nemzeti és regionális parkok épitése).

A magyar területfejlesztési politikában is többé-kevésbé ismertek ezek a célok: az elmaradott térségek iparfejlesztése fóként az Alföldön, az ellenpólus városok (az 5 megyei jogú város) fejlesztése Budapest ellensúlyozására, az új városok építésére (amelyek Franciaországban a nagyvárosok köré, azok tehermentesítésére jöttek létre, nálunk egy-egy új nehézipari óriásvállalat munkásait koncentrálták). A 70-es évek magyar programjaiban jelent csak meg a településhálózat hierarchikus rendszere és az e rendszer mentén haladó infrastrukturális fejlesztés, amely a középvárosok fejlôdésének nyújtott kedvezốbb feltételeket. A 70-es évek közepén indult el a falufejlesztési program, amelynek célja nem a falvak megmentése volt, mint Franciaországban, hanem a jelentôs arányú és stabilizálódott falusi népesség életkörülményeinek javítása a városi infrastruktúra tehermentesítése érdekében. A környezetvédelem fontosságának hăngsúlyozása mindvégig bizonyos ellenzéki politikai színezetet viselt magán, és csak a rendszerváltás után vált a kormányprogram részévé.

A területfejlesztési politika eredményei

Az 1975-ben tartott népszámlálás szerint az aktív regionális politika kezdte meghozni az eredményeit. A párizsi bevándorlási hullám lenyugodott, az ország nyugati és délnyugati részébôl csökkent az elvándorlás. Az ellenpólus nagyvárosok gyorsabban nôttek, mint Párizs, a kisés középvárosok gyorsabban, mint a nagyvárosok. A gazdaság térbeli különbségeinek csökkenése nem volt ennyire bíztató. Az ipari munkahelyek száma ugyan gyorsabban nôtt a nyugati területeken, mint az országos átlag, ám Északon és Keleten a dezindusztrializáció folyamata indult el, a válság jeleit mutatva a tradicionális kohászati, szénbányász és textilipari körzetben. A jövedelmek is elég jelentôs területi szóródást mutattak (a Párizs-környéki egy főre jutó jövedelem kétharmadát lehetett kimutatni a Rhone-Alpok vidékén, és Bretagne-ban, a legelmaradottabb területen, a jövedelmek a párizsi agglomeráció szintjének csupán felét tették ki).

Magyarországon az 1970-es években már megszūntek a regionális foglalkoztatási problémák; Budapesten, majd késốbb a nagyvárosokban, a munkaerố égetổ hiánya kezdett kialakulni. A területi jövedelmi különbségek jelentôs mértékben kiegyenlítődtek. 
Mindazonáltal Budapest és agglomerációjának részaránya nem csökkent sem az ország népességében, sem az ország gazdaságában. Ez utóbbi elsôsorban nem a nemzeti jövedelem fốvárosi részarányára vonatkozott, hanem fốként a gazdasági és politikai hatalom centralizálására.

A megyei székhelyek azonban szintén fontos városokká váltak, és kialakult a középvárosokból álló városhálózat.

Hangsúlyozni kell azonban, hogy a területfejlesztési programok Magyarországon csupán megfogalmazott és jórészt csak papíron maradt programok voltak. A területi politika valójában nem érvényesülhetett az ágazati politika mellett, fôképpen nem azzal szemben. A térbeli gazdasági differenciálódás elsốsorban a gazdaság- (fóként az ipar-) politikának, mintsem a hatáskörök nélküli településfejlesztési politikának volt a függvénye. A redisztribuciós folyamatnak, mely a jól múködố vállalatoktól elvonta az átlagon felüli nyereséget, a ráfizetéses, gazdaságtalan vállalatokat pedig - legalábbis fennmaradásuk mértékéig - támogatta, területi szintú kiegyenlítớ, illetve differenciáló hatását még máig sem ismerjük pontosan. Az azonban nyilvánvaló, hogy ezek a beavatkozások játszották a meghatározó szerepet a területi különbségek kialakulásában, nem pedig a területfejlesztésre fordítható beruházások.

\section{A defenzív területfejlesztési politika 1975 után}

Jó tíz éven át haladt még a francia területfejlesztési politika az állami területfejlesztő intézmény, a D.A.T.A.R. által kidolgozott elvek, tervek mentén, dinamizmusa azonban egyre inkább alábbhagyott. Csak az 1980-as évek második felében indultak el azok a viták, amelyek megkérdôjelezték az addigi alapelveket, a felhasznált módszereket és eszközöket, az elért eredményeket, vagyis a területfejlesztési politikát magát. A vita jelenleg is folyik, nemcsak Franciaországban, hanem a fejlett világban mindenütt. Abban többnyire egyetértenek a vitatkozók, hogy új feltételek között új célok formálódtak, megváltozott az állam szerepe, megváltozott a felhasználható módszerek, eszközök tára. A vita elsősorban arról folyik, hogy ezek az új körülmények átmenetileg, vagy véglegesen lezárják-e a területfejlesztésnek azt a korszakát, amely szociális vagy gazdasági érvek alapján a nemzet régiói közötti különbségek csökkentésében jelölte meg céljait.

\section{Meguáltozott feltételek}

Az 1970-es évek közepének gazdasági válsága, és az e válságra válaszul adott második ipari forradalom megérttette a világgal, hogy a gazdasági növekedés három évtizedes korszaka végetért, az emberiség a gazdasági fejlôdés új szakaszába lépett. Világméretủ átrendezôdés indult meg, új növekedési központokkal, és új válságtérségek kialakulásával. Többek között a szocialista rendszer jóformán teljes összeomlása is ezekkel a változásokkal van összefüggésben.

A kialakult új feltételek a nemzeti területfejlesztési politikákat is alapvetôen érintették. A gazdasági növekedés lelassulásával, sốt stagnálásával eltűnt az az anyagi forrás, amelyet azidáig az állam, többek között a területfejlesztésre, a térbeli különbségek kiegyenlítésére fordíthatott. Ez volt az a ,,többlet”, amely olymódon szolgálhatta az elmaradott területek fejlesztését, hogy nem sértette meg a fejlett térségek gazdasági újratermelési folyamatait. 
Barta Györgyi: Fordulóponton a magyar területfejlesztési politika, avagy szem elöl veszítjük-e a francia mintát? Tér és Társadalom, 6. 1992. 1-2. 17-35. p.

TÉT $1992 \cdot 1-2$

Fordulóponton a magyar településfejlesztési politika...

Az ipari forradalom következtében kialakuló új gazdasági-ipari struktúra egyrészt elmélyítette az általános munkanélküliséget, az új technológia által feleslegessé téve a munkaeró egy részét, másrészt strukturális munkanélküliséget gerjesztett a tradicionális ipari ágazatok válságba jutásával. Olyan térségek váltak válságterületekké, amelyek korábban a legfontosabb iparterületeknek számítottak (Franciaországban az északi és keleti térségben). Elindult a dezindusztrializáció, a térségeket nem tradicionális iparterületeknek, hanem ipari konverziós térségeknek nevezik ezután. Az ipari termelés súlypontja Franciaország nyugati és délnyugati vidékére helyezôdik át. A korábban fejlett ipari térségeket, és fốként a párizsi agglomerációt, a tercierizálódás (a mũszaki tudományok, technika, informatika, banki tevékenység, biztosítás, közlekedés, távközlés és egyéb szolgáltatások a kutatótevékenység, a felsôoktatás dominanciája stb.), az ipari irányító és ellenốrzô székhelyek további koncentrálódása (lle de France-ból irányítják közvetlenül a francia ipar $44 \%$-át!) jellemzi. De nehéz helyzetbe kerültek a kevésbé iparosított területek is, amelyek az ipar térbeli átrendezôdéséból korábban kimaradtak (Massif Central déli területei, a Lorraine vidéke, a Pireneusok lejtôi).

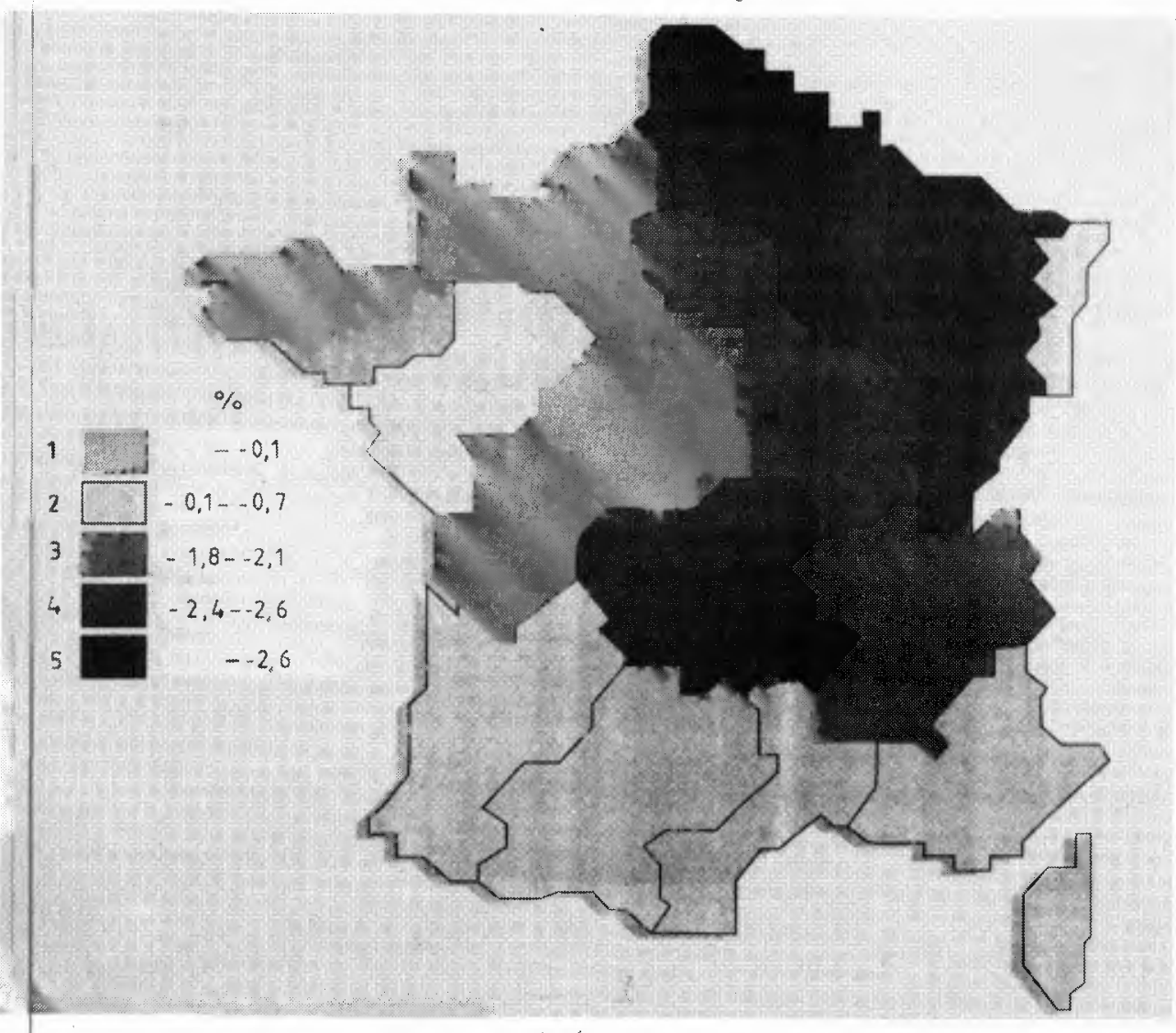

1. ÁBRA

Az ipari foglalkoztatottak arányának változása 1980 és 1986 között

(Changes in the proportion of industrial employees between 1980-1986) 


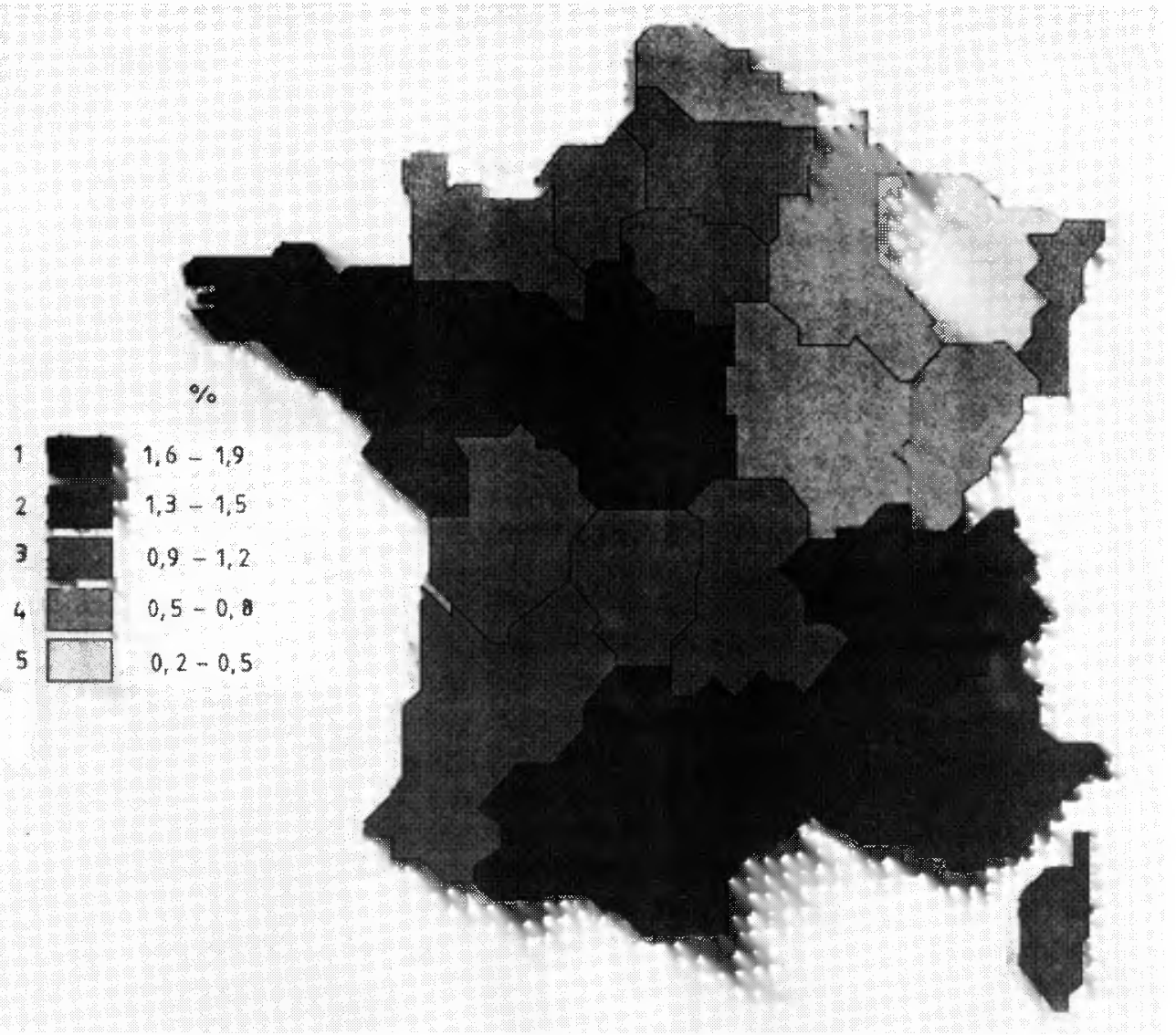

2. ÁBRA

A tercier ágazatokban foglalkoztatottak számának növekedése 1980 és 1986 között (Increase in the number of employees in the terciary sector between 1980 and 1986)

Forrás: INSEE

\section{Az állam megváltozott helyzete}

Az állam szerepének megváltozását, pontosabban helyzetének meggyengülését a területfejlesztésben közel sem csak az állam által felhasználható anyagi eszközök beszúkülése okozta. A decentralizációért vívott küzdelem végülis 1982-ben a régiók önállóságának kiteljesedését jelentette. Az új regionális reform szerint a régió olyan területi közösséggé vált, amelyet a közvetlen általános szavazással megválasztott közgyưlés irányít, és amelynek elnöke a végrehajtó hatalmat is birtokolja. A régió így teljhatalommal rendelkezik a döntések kidolgozásában és végrehajtásában. A közigazgatás decentralizációja, amit másképpen regionalizációnak is ne- 
Barta Györgyi: Fordulóponton a magyar területfejlesztési politika, avagy szem elöl veszítjük-e a francia mintát? Tér és Társadalom, 6. 1992. 1-2. 17-35. p.

TÉTT $1992 \cdot 1-2$

Fordulóponton a magyar településfejlesztési politika...

25

veznek, nemcsak Franciaországban jutott eredményre, de végigsöpört egész Nyugat-Európán, szembetũnô változást hozva például Belgiumban, ahol három önálló régió alakult ki (Brüsszel, flamand és a vallon régió) önálló törvényhozással, önálló döntéshozási jogkörökkel. Az állam, a központi hatalom, amely ezidáig egyedül döntött a területfejlesztés kérdéseiben, kooperációra kényszerült a régiókkal. Sokdimenziós tárgyalás indult el az állam és a régiók, az állami szektor és a magánszektor között. Franciaországban a Contrats de Plan État - Région, vagyis az állam és a régiók közötti szerzốdésekben rögzítik a területfejlesztésre vonatkozó célokat, megállapodásokat. A régiókkal egyeztetett állami támogatások a régiók pénzügyi kötelezettségét is tartalmazzák, így a régiók sokkal óvatosabbakká váitak a foglalkoztatás bốvítésére és az új vállalatok létesítésére vonatkozó állami szubvenciók igénylése terén.

Nem kétséges, hogy a decentralizálódás pozitív folyamatának negatív következményei is vannak. Ilyen intézményi keretek között nincs mód, vagy legalábbis megcsappantak a lehetôségek az elmaradott régiók támogatására, amely a regionális különbségek nyîl vánvaló növekedéséhez vezet.

Ma már a D.A.T.A.R. szükségessége körül is viták folynak, hiszen a kialakult új helyzetben rendkívül beszúkuuilt annak lehetốsége, hogy a D.A.T.A.R. betöltse korábbi társadalmi-gazdasági szerepét.

\section{A területfejlesztésben alkalmazott módszerek, eszközök megváltozása}

Az új ipari forradalom térhódítása megváltoztatja a területi munkamegosztás rendszerét, lehetốvé teszi az ipari tevékenységek decentralizálását, mégpedig a 60-as évek áttelepítési folyamataitól eltérố formában. Az új távközlési technikák megjelenése alapja lesz a nagytávolságú munkamegosztásnak. Az ipari tevékenységhez kötôdổ tercier és kvaterner tevékenység az új gazdasági struktúrában a korábbinál nagyobb részarányúvá válik, és elsôsorban a nagyvárosokba koncentrálódik. A tradicionális ipari tevékenység kiköltözik a nagyvárosokból.

A gazdasági fejlốdés motorja az iparhoz kapcsolódó tercier és kvaterner szektor lesz, érthetố tehát, hogy a területfejlesztôk figyelme is a vállalkozások környezete, körülményei felé fordul: a közlekedés, távközlés, ill. az emberi, nem-anyagi tốke javítására (oktatás, képzés, a technika, technológia, az innováció kérdései).

Franciaországban igen fontos szerepet töltött be korábban a tervezés; a gazdasági és a területfejlesztési politika is tervekbe foglalta a programját. 1976-tól a tervezés fokozatosan formálissá vált, középtávú célkitũzései, a növekvô infláció és a fokozódó munkanélküliség miatt, rendre nem teljesültek. Az óvatos tervek késốbb már csak irányokat szabtak meg és prioritásokat jelöltek ki. Valójában a decentralizáció tette teljesen lehetetlenné a tervezés rendszerét. Az állam és a régiók közötti tervszerzôdésekben két prioritás ismétloódik rendszeresen: a vállalkozásokban való közös részvétel, és az új technológiák bevezetésének elôsegítése. Az állam-régió tervszerzôdések összefogására egy erốs szervezetre lenne azonban szükség, (a D.A.T.A.R. szerint), amely képes lenne fenntartani a nemzeti és a decentralizált regionális érdekek között kívánatos harmóniát. 


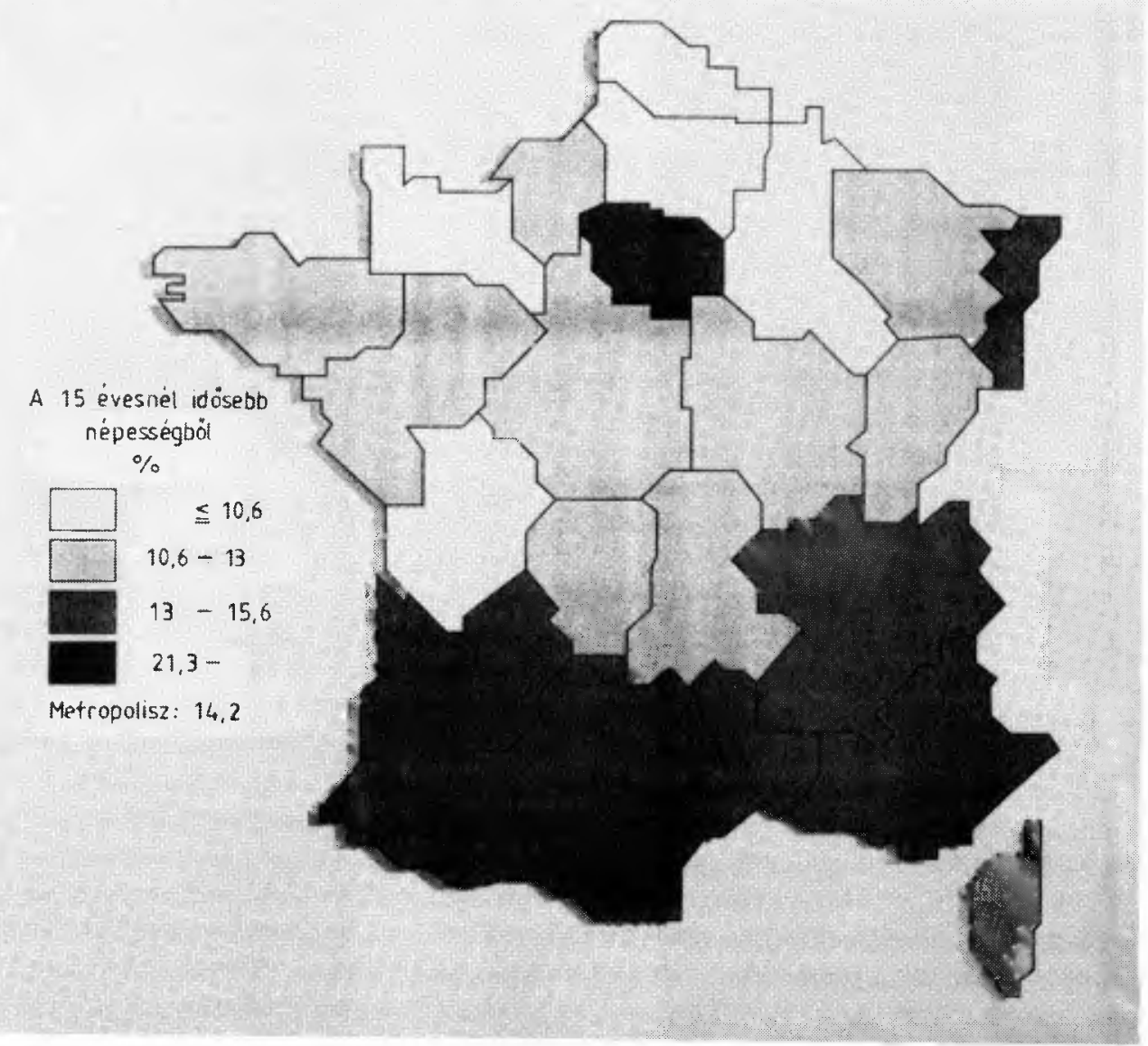

3. ÁBRA

Érettségivel és felsófokú végzettséggel rendelkezók arânya

(Proportion of college- and university-educated of the population over 15 years of age)

Forrás: INSEE

Új cél: az európai dimenzió és a francia érdekek összehangolása

Ez évben, 1992-ben, jön létre az Európai Közösség egységes piaca; ezzel a regionális különbségek problémája kilép a nemzeti keretek közül, és európai dimenziójú lesz. Franciaország, amely az Európai Közösség országainak fejlettségi rangsorában középen helyezkedik el, általánosságban nem számíthat jelentốs támogatásra. Sốt, az eddig fejletlennek tartott francia régiók esélyei is romlanak a spanyol és a portugál alacsony szint miatt (viszont a Spanyolországban eddig legfejlettebbnek nyilvánított Catalonia is remélhetỉ az Európai Közösség támogatását). 
Barta Györgyi: Fordulóponton a magyar területfejlesztési politika, avagy szem elöl veszítjük-e a francia mintát? Tér és Társadalom, 6. 1992. 1-2. 17-35. p.

TÉT $1992 \cdot 1-2$

Fordulóponton a magyar településfejlesztési politika...

27

A megnövekvổ piac azonban megsokszorozza a fejlettebb országok, így Franciaország esélyeit, lehetôségeit is. A kiterjedt piac elérhetôsége, vagyis a közlekedés, távközlés fejlesztése, segíti legjobban a francia régiók fejlődését jelenleg. Ennek érdekében tervezik az európai dimenziót figyelembe vevô autópálya-rendszer átépítését, amely most már nem Párizs-centrikus lesz, és a TGV (a nagy sebességư vasút) hálózat bốvítését. Befejezés elốtt áll az Angliát és Franciaországot a La Manche csatorna alatt összekötố alagút építése is.

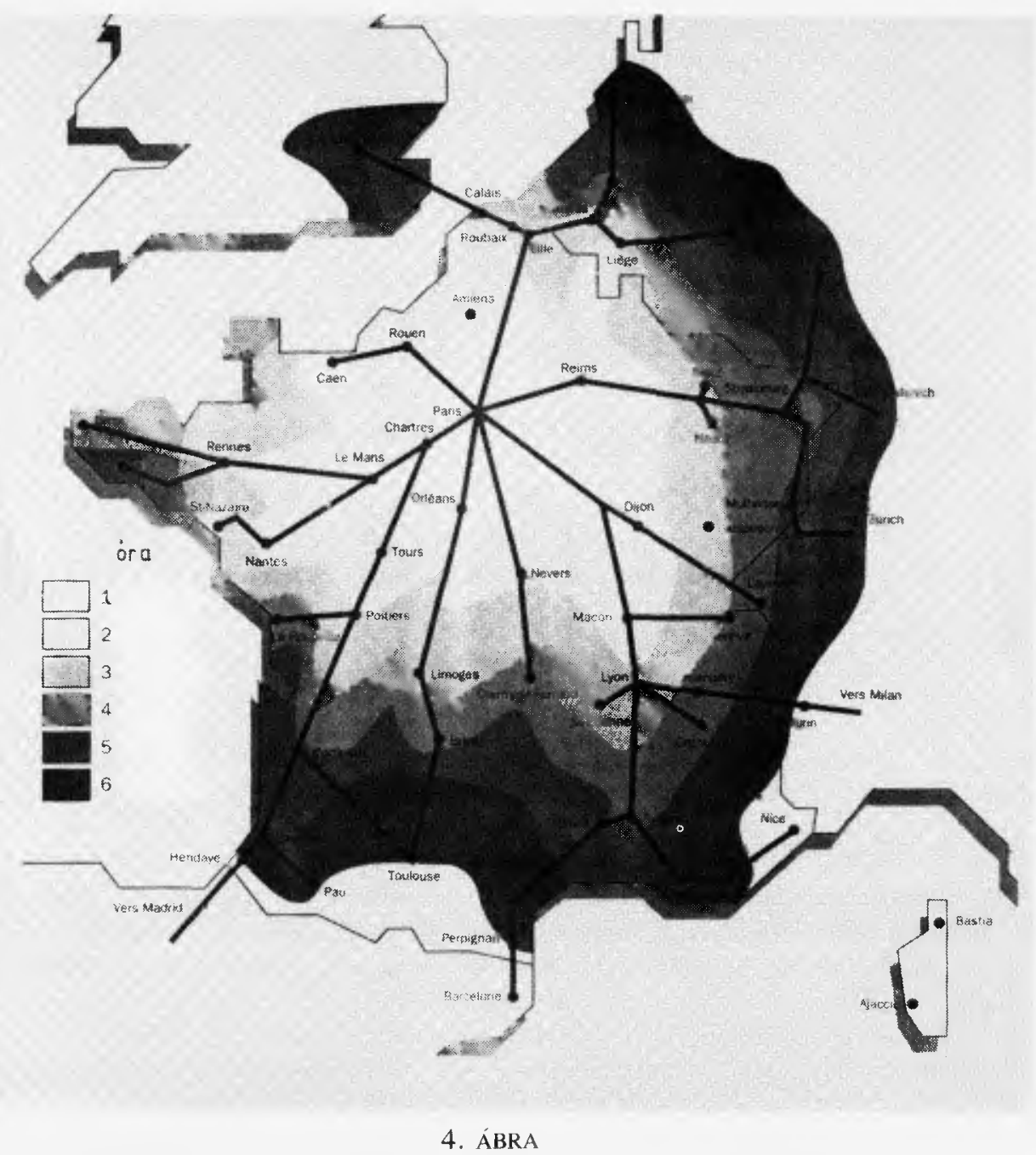

A tervezett nagy sebességü vasútvonalak (TGV) és az elérhetöség idóigénye

(The planned high-speed railway lines and their accessibility)

Forrás: DATAR 


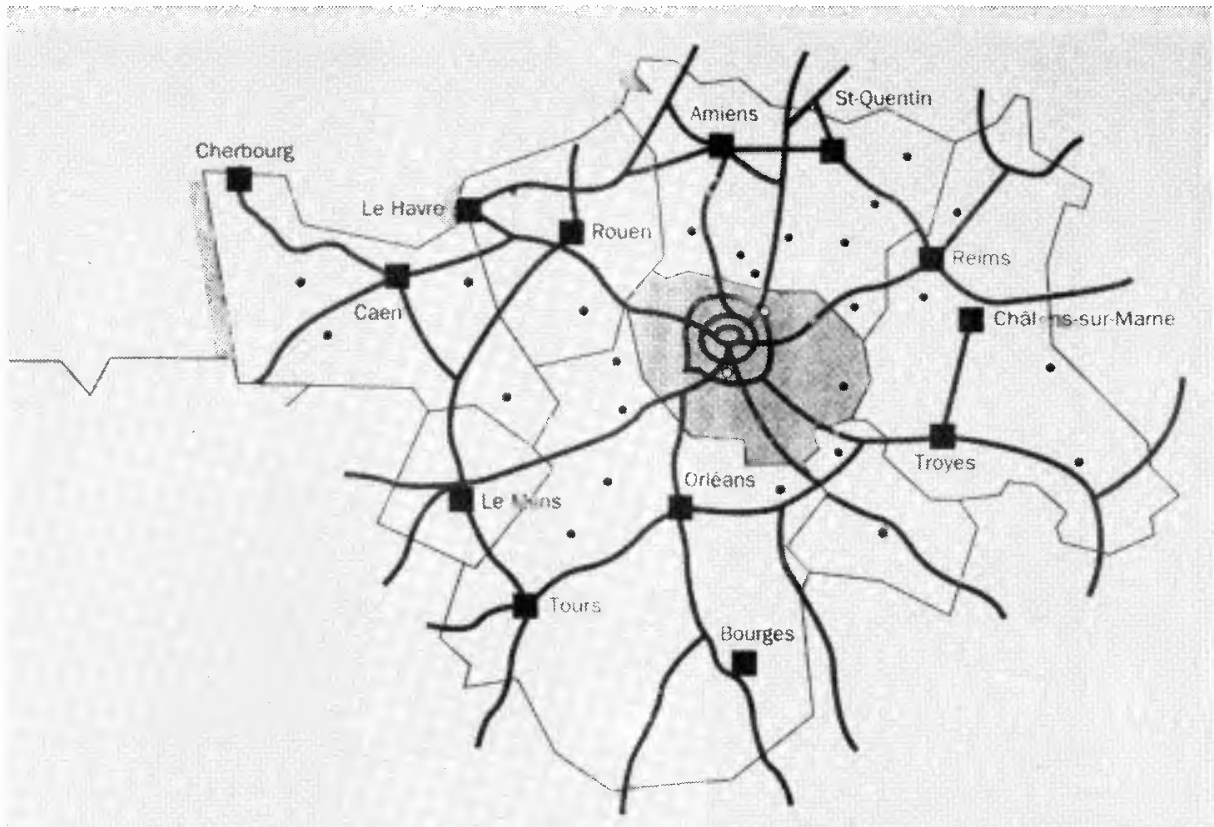

5. ÁBRA

A Párizs körüli autópályák tervei

(Plans of the highways around Paris)

Forrás: Propositions du Livre balnc de I'Ille-de-France IAURIF

\section{A területfejlesztési politika jelenlegi eröfeszítései Franciaországban}

Makroökonómiai kontextusban a területfejlesztési feladatok másodlagossá válnak a foglalkoztatási problémák, illetve az állami szociálpolitika gondjai mellett. A területfejlesztés dinamikus korszakában, szerte Európában, regionális szintû automatikus támogatási rendszer múködött, amely bizonyos zónákat, ill. bizonyos célkitúzéseket preferált. Ez az automatizmus kezd eltưnni Nyugat-Európából, és elsốsorban egyéni és szelektív megoldásokat (helyi , ,tũzoltó" politika) alkalmaznak. Franciaország egyelőre fenntartja automatikus támogatási rendszerét, amelyet azonban egyre több támadás ér. A kormányok többsége nyíltan, vagy leplezett formában feladta a korábbi automatikus területi támogatási rendszert.

Franciaországban még zónánként differenciált támogatási rendszer müködik. Elsốsorban a helyi foglalkoztatás bớvítését jutalmazzák, az új munkahelyekre adott fix összeggel. Fenntartják a lokális, alkalomszerû́ beavatkozás lehetôségét is, elsốsorban a bajba jutott vállalatoka1 


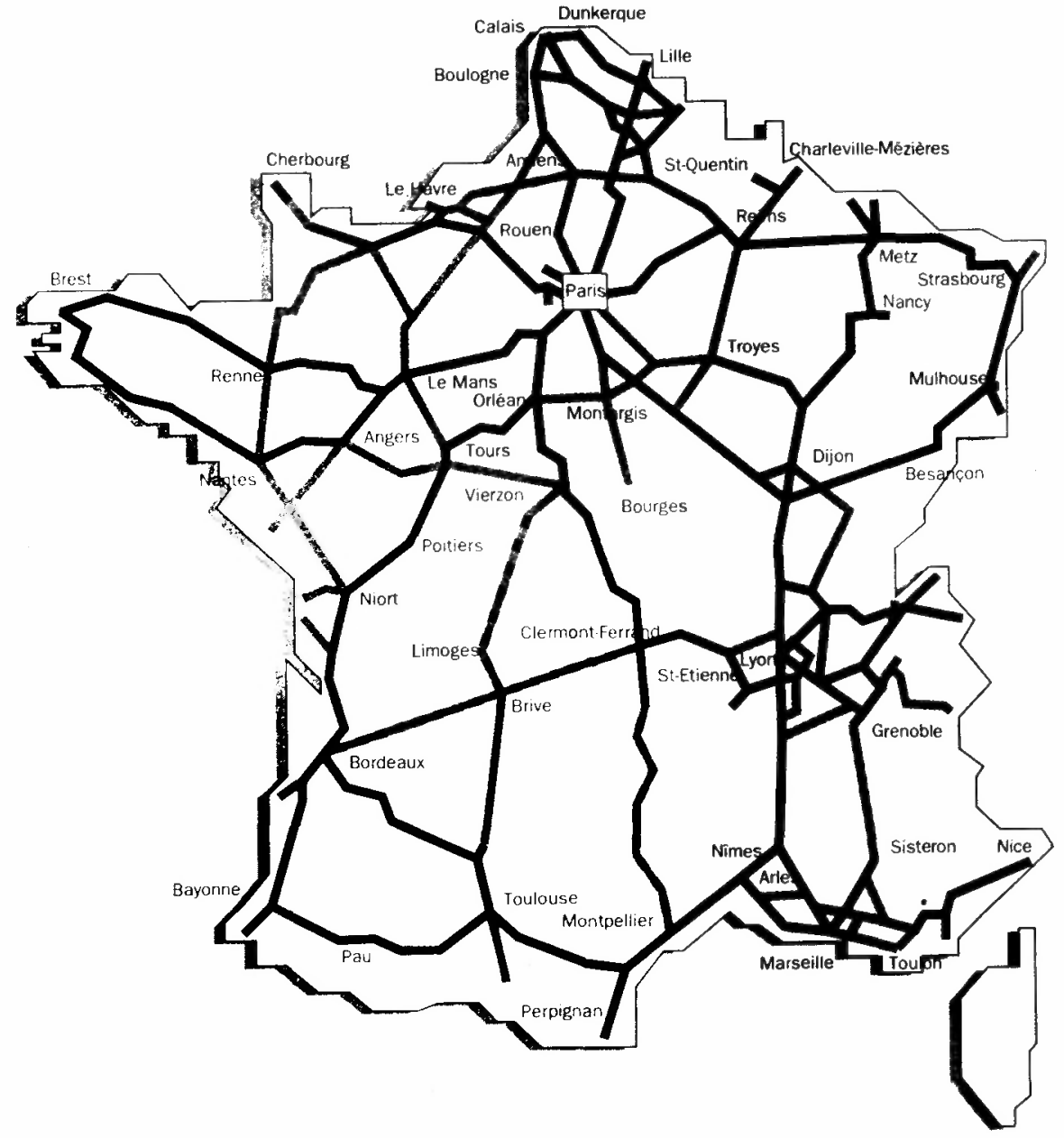

\footnotetext{
autópályák és gyorsforgaimi autóutak, amelyek már 1990. január 1-én müködtek

- (motorways and highways in use on January 1, 1990.)

morvezett utak (planned roads)
}

\section{6. ÁBRA}

Autópályák és gyorsforgalmi utak

(Highways and motorways)

Forrás: DATAR 
segítik ki. Az ipari átstrukturálódás mintegy 14 zónáját jelölték ki, az ún. átalakulási pólusokat (pôles de conversion), ahol fóként a tradicionális tevékenység visszaszorulását kezelik.

A párizsi régióban (Ile de France) eltörölték a bốvítést sújtó korlátozásokat az európai metropoliszok hálózatában, mivel fontosabbnak vélték Párizs nemzetközi verseny képességének erósítését. A kormány területfejlesztési politikája kedvezményeket nyújt a külföldi tőkeberuházásoknak a prioritást élvezố zónákban.

\section{Gondolatok a magyar területfejlesztési politika jövôjéról}

Magyarország nehéz gazdasági helyzetben van. Egy idóben szakadt a gazdaságra a strukturaváltás kényszere (a nehézipar, ezen belül is a kohászat, a szénbányászat visszaesése stb.), a piacváltás gondja (a keleti piac összeomlása, a nyugati piac magasabb színvonalú és eltéró igénye), a hazai kereslet beszúkülése, a szervezeti átalakulás és a privatizáció okozta bizonytalanságok. A változó körülmények egyszerre sodortak válságba különböző gazdasági szerkezetú térségeket, ahol a válságot általában nem is egy tényező, hanem több tényezó egymásra hatása, halmozódása okozza. Jóformán az ország egész területe különbözó mélységũ vál ságproblémákkal jellemezhetố a budapesti agglomerációtól eltekintve, amely gyökeres struktúraváltáson megy keresztül, ledobva magáról a szocialista fóváros ruháját, és egyre nyilvánvalóbban viselve a metropolisz jellemvonásokat. A fóváros és a vidék között így gyorsan növekednek a különbségek, vannak akik az oszág szétszakadásáról beszélnek; szerintem inkább felgyorsuló polarizálódásról van szó, tovább erôsítve a centrum-periféria jelleget.

A területi folyamatok, a regionális válságjelenségek, a növekvô térbeli különbségek átgondolt területfejlesztési politikát követelnének, jobban, mint bármikor ezidáig. E regionális válságoldó programok elindításához, a területi folyamatok kiegyensúlyozásához viszont kevesebb a lehetôség, az erổ, az elgondolás, mint valaha.

Miról is van szó?

A területfejlesztés tehetetlenségét nem lehet egyszerúen pénzhiánnyal magyarázni. A szegénység, a tartalékok hiánya, csak az egyik ok.

Három másik okot említenék inkább a jelenlegi patthelyzet magyarázatra.

- Az egyik egy speciálisan kelet-európai adottság, amely a politikai-gazdasági rendszerváltásból következik. Az új rendszerben fokozatosan csökken az állam beavatkozási lehetôsége, a redisztribució mértéke visszaszorul. Ez elvileg is szükíti a térbeli kiegyenlítés lehetôségét.

Hozzá kell még számítani azt a tényt, hogy a területfejlesztés mindig az ágazati tervezés és irányítás árnyékában maradt. Tehát valójában nem is létezett aktív területfejlesztési politika (bár elvileg létezhetett volna!)

- A másik ok nemzetközi jelenség; a gazdasági növekedés megtorpanása, sốt Magyarországon a gazdasági visszaesés ténye ,,megspékelve” az ország súlyos eladósodottságával. Beszúkültek, talán meg is szû̉ntek nálunk is azok az anyagi források, amelyek eloszthatók lennének, anélkül, hogy az elvonás fenyegetné a bővített újratermelést. A kormány, nálunk 
is, a területi válságnál súlyosabbnak ítélt makroökonómiai problémákat kezeli; elsốsorban a munkanélküliség és a foglalkoztatás generális problémáját, valamint igyekszik elổsegíteni a szerkezeti átalakulás felgyorsítását. A regionális válság másodrendư kérdés az említett feladatok mögött.

Úgynevezett tũzoltóprogramokat szerveznek inkább, egy-egy település, térség kritikus helyzetének javítására.

- Érdemes egy kicsit megállni a következô problémánál. A fejlett nyugat-európai országokban az állam kivonulása a területfejlesztésból egyszersmind azzal jár, hogy a feladatok a helyi, regionális hatáskörbe lettek ,áttolva”. Ez kétségtelenül azt hozta magával, hogy a tehetôsebb régiók könnyebben bírkóznak meg a feladataikkal, mint a gyengébbek. Mindemellett felhívja a figyelmet arra, hogy a decentralizációs folyamatok eredményeképpen kialakultak azok az intézményi struktúrák, létrejött a felhalmozásnak és elosztásnak az a területi rendszere, ,,kinevelổött” az a felelósséget és szakmáját jól ismerổ garnitúra, amely lehetôvé teszi, hogy a területi feladatok megoldását állami hatáskörbôll lokális szintre tegyék át.

Magyarországon a közigazgatás átszervezésével jelentôsen bôvültek a települések hatáskörei, jogai saját sorsuk rendezésére, a települések azonban önmagukban erốtlenek ehhez a feladathoz. A megyei tanácsok megszủnésével viszont a megyei szint rendkívül meggyengült. Sokkal inkább erôsödnek az állam megyei bástyái, mint az önálló megyei közigazgatás. Mindez azt jẹlenti, hogy nálunk nem lehet áttolni azoknak a feladatoknak a megoldását helyi szintre, amelyre az állam képtelenné vált.

El lehetne gondolkozni azon, hogy itt lenne a lehetôség a regionális szint létrehozására, két feladatot oldva meg ezzel: egyrészt a helyi problémák kezelésére alkalmas szervezet jönne létre, másrészt a megyék kis egységeit lehetne felváltani 5-7 régióval, mint ahogy arra már voltak sikertelen kísérletek.

Feltehetố a kérdés: mihez képest kicsik a megyék? A választ most már könnyebben meg lehet adni: az európai régiókhoz, az európai közigazgatás egyre nagyobb hatalommal rendelkezố egységeihez képest. És itt érkeztünk el ahhoz a kérdéshez, amellyel sokat foglalkoztunk, de nem eleget.

Magyarország fejlôdését, gazdasági struktúrájának átalakítását, új ágazati és területi intézményrend szerét olyan irányba kell formálni, hogy az ország egyre inkább képes legyen a nyitásra, az európai vérkeringésbe való bekapcsolódásra.

Ennek egyik feltétele lenne a regionális lépték kialakítása, és az eddigi állami-megyei hatáskörök regionális szintre való áthelyezése.

A másik feladat az állam és a régiók együttmû́ködésével az ország, és ezen belül a régiók elérhetốségének javítása lenne. Ki kell építeni az autópályák rendszerét, korszerüsíteni kell a vasúti közlekedést, oldani kellene az eddigi sugaras szerkezetet, meg kellene teremteni ill. fejleszteni kellene a távközlés infrastruktúráját.

A , herdver" mellett fokozott erôfeszítést kellene fordítani a ,,softverre" is, a humán és nem anyagi jellegủ fejlesztésre. Az oktatás új területi rendszere, színvonalának általános emelése, az új követelményekre jobban felkészító képzés és átképzés, a vállalkozói mentalitás kialakulásănak segítése, a nemzetközi folyamatok jobb megélése (ennek csak az egyik fontos része a nyelvtudás) most alapkérdés Magyarország jövôjét illetôen. Az oktatás és a kultúra decentrali- 
zációjára tett kísérletek sem Franciaországban, sem nálunk nem jártak sikerrel. Az erốfeszítést a vidéki hálózat bôvítésére és fejlesztésére kellene koncentrálni. Ez is állami feladat marad. És végül még egy vitás kérdés: Budapest és a vidék konfliktusa. Európai szintre helyezve ezt a problémát, fel sem vetổdhet újra Budapest növekedésének, fejlổdésének korlátozása. Budapest az egyetlen magyar város, de Kelet-Európában is bizonyos elổnyökkel rendelkezik ahhoz, hogy nemzetközi várossá váljék, hogy bekapcsolódhasson az európai metropoliszok hálózatába. Ez most az igazi fejlôdést jelentheti számunkra, és ezt az esélyt nem szabad elszalasztani szũklátókörû̉, csak az országhatárok közé zárt szemlélet továbbéltetésével, vagy felélesztésével.

\section{A felhasznált irodalom}

R. Brunet (1990): Le territoire dans les turbulences, Urbaine Géopraphiques, Reclus, Maison de la Géographie, Montpellier

J. Lajugie (1989): Un tiers des siécle d'aménagement volontariste du territoíre, Revue d'Economic Régionales et Urbaine (RERU), No. 1.

J. M. Uhaldeborde (1989): Qui doit financer l'aménagement du territoire? $R E R U, \mathbf{N} .1$.

A. Piatier (1989): Aménagement du territoire et mouvements longs, RERU, No. 1.

J. Chérèque (1990): Une nouvelle étape pour l'aménagement du territoire, DATAR La documentation Francaise, Paris.

R. Brunet (1989): L'aménagement du territoire: nouvelles donnes? Débat, L'Espace géographique, No. 4.

P. Duboscq (1989): Aménagement territorial, dialectiqule identitaire: la France d'aprés 1974, L'Espace géographique, No. 4.

H. Beguin (1989): Efficcité et équité en aménagement du territoire, L'Espace géograhique, No. 4.

R. Prud' Homme (1991): Tendances de développement économique spatial en Europe vers une aggravation des disparités? Prospective et Territoires, Document DATAR

R. Hertzog (1991): La taille des collectivités locales: Un faux - debat exemplaire, Prospective et Territoire, Docoment DATAR (Dec).

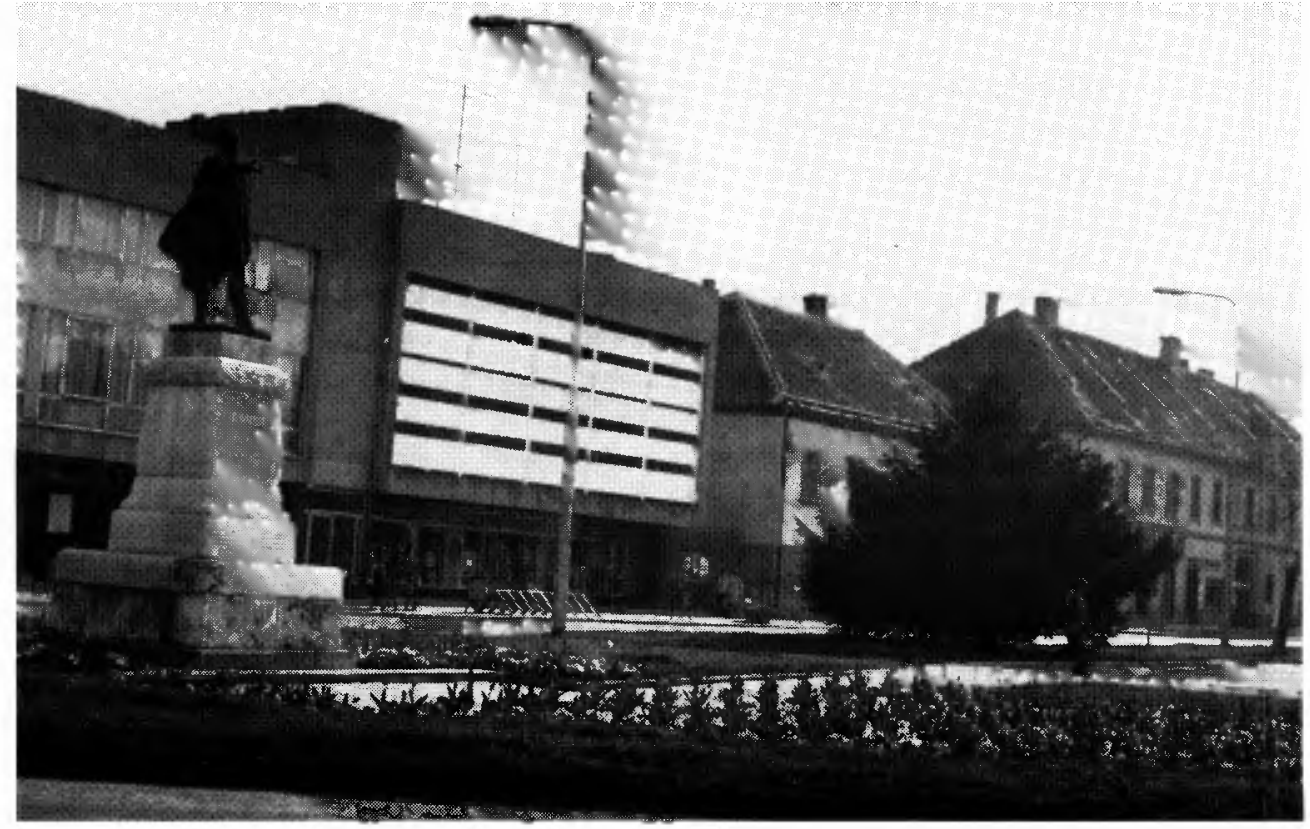




\section{IS HUNGARIAN REGIONAL DEVELOPMENT POLICY AT A TURNING POINT, OR ARE WE LOSING SIGHT OF THE FRENCH EXAMPLE?}

\section{GYÖRGYI BARTA}

In Hungary, the elaboration of regional development policy started in the $1960 \mathrm{~s}$. The 30 years of regional development policy are evaluated in the most extreme ways; There are some who find this activity fundamentally successful, as has it reached its most important goal, the moderation of regional-aconomic-social differences. Others question whether regional development policy had any influence whatsoever on the regional changes of the socioeconomic processes. However, neither the affirmative nor the doubting opinions deny that the regional development policy was the product of the socialist economic system between 1961 and 1989 , and that this system was characterized by both the general socialist and the specific Hungarian features. Consequently, its success and failures can be explained exactly with these characteristics.

When studying the history of French regional development policy, strange similarities can be found between the French and the Hungarian intentions, and these similarities are not accidental at all. The French regional development policy served as an example for the Hungarian experts already in the very beginning. France, which is far more centralized than the other West-European countries, can be a pattern, and a kind of ,,reference country" for the Hungary in transition these days. In France, regional development policy became an integrated part of the government policy, because the French accept quite well the idea of caring about underdeveloped regions, and as the conflict between the overdeveloped capital city and the rest of the country has always been and still is a fundamental issue.

However, highlighting the above similarities in development can be interesting in itself, just by showing the different results brought about by similar efforts in the two countries with different political systems and levels of economic development. The parallel tendencies, that could be detected in France until the mid-1970s, and in Hungary until the end of the 1980s, are over now. The new economic conditions weakened the French regional development policy. DATAR worded and announced its new economic development policy during the last one or two years as an answer to the challenges of new economic, social and political conditions. The Hungarian regional development policy has also weakened, its ideological foundations are shaken, the efforts to ease social and economic inequalities have become extremely timely and, at the same time, outdated, and the financial resources of regional development are more limited than ever. Does Hungarian regional development policy pay any attention to the French example, which fights for preserving its positive traditions, or will the spatial influences of spontaneous market proecesses gain ground? In my opinion, this is a good enough reason to learn more about the present French regional policy.

The beginnings of the French regional development policy can be dated back to the 1950s. In the middle of the 20th century, two basic spatial conflicts became extremely strong in France: one of them was the conflict between the overg rown capital city, Paris, and the rest of the country 
(one-sixth of the population in France was concentrated in Seine and Oise counties, while only one-twentieth had lived in this region a hundred years before; in the first half of the century, the number of industrial employees increased by $50 \%$ in the Paris agglomeration, while the national average was only $3 \%$; in the 1950 s, Paris concentrated $70 \%$ of bank employees, $60 \%$ of business turnover, and $40 \%$ of higher education) and the other conflict could be identified among the rural regions (East of the Le Havre-Marseille axis, the living standards were twice or three times higher than in the regions West of the axis). It was the time when the first general regional development policy was worded, and its classical elements - decentralized industrial development, modernization of agriculture, development of tourism and infrastructure, decentralization of culture - were applied by all those countries where regional development was taken into consideration. The necessity of the development of underdeveloped regions was codified by law in 1955-56, and this was extended with two more regulations: the adminsitrative prevention of the further growth of the Paris region (the foundation of industrial enterprises exceeding a certain size had to be licensed in advance, permissions to construct new offices and scientific institutions would not be granted for 3 years), and the establishment of an economic and regional development fund (Fonds de Dévéloppement Économique et Social) to cover the relocation costs of industries and the costs of establishing new industries in the regions to be developed. This was the time when the comprehensive development program of the 22 regions was elaborated.

This regional development project was not too very successful. The companies relocated from Paris tried to settle down in a $200-\mathrm{km}$ radius from the capital city. The efforts to decentralize the scientific and educational institutions ended up in complete failure.

The Hungarian regional develoment project applied the above measures only in part and at a later date, but did not learn anything of its failures. The decentralization of industry and the modernization of agriculture were accepted, but the infrastructural development was neglected, not to speak about the decentralization of culture. The administrative economic regulations which aimed to stop the development of Budapest were extended, in addition to increasing the severity of regulations on settling down in Budapest. The Regional Development Fund was created fairly late, only in 1971, and it was an insignificant amount and gave about $1 \%$ of the industrial investments of the time, and oriented only about $4-5 \%$ of all the investments. After some years, the Regional Development fund ceased to exist. Until the mid-1970s, VÁTI (Scientific Institute for Urban Development) elaborated development plans for the counties, which were similar to the French development projects.

The French were lucky to draw the conclusions on the inefficiency of the means and methods of regional development policy already in the period of prosperity. In the mid-1960s, there was a chance to initiate new, global regional development activities. The French were aware that no regional development project could be succesful without overall decentralization. Decentralization of power is the most delicate and most difficult issue, and its success could be celebrated by the French only several years after the implementation. Under Hungarian conditions, no decentralization could take place as it contradicted the rules and principles of the socialist regime. Though the role of county councils increased from the 1970 s, they remained primarily the executors of central decisions, and had very little field for independant activities. The new economic mechanism, which granted rather big independence to the 
Barta Györgyi: Fordulóponton a magyar területfejlesztési politika, avagy szem elöl veszítjük-e a francia mintát? Tér és Társadalom, 6. 1992. 1-2. 17-35. p.

companies, did not touch the institutional structure. In the period of economic prosperity, in the 1960 s and 1970 s, production was spread all over the country, but the management and control of production remained centralized.

,,Divison industry" became dominant in large zones and counties, but it had no roots, and did not generate further development in the neighbourhood. Consequently, these industries soun, got into an uncertain position due to unfavourable economic conditions. It is not accidental that this industrialization project was called colonialization. Though the population increase and the effective growth of the economy could be stopped in the administrative area of Budapest, the agglomeration of Budapest developed dynamically, and its population density increased rapidly.

Translated by J. Mészáros

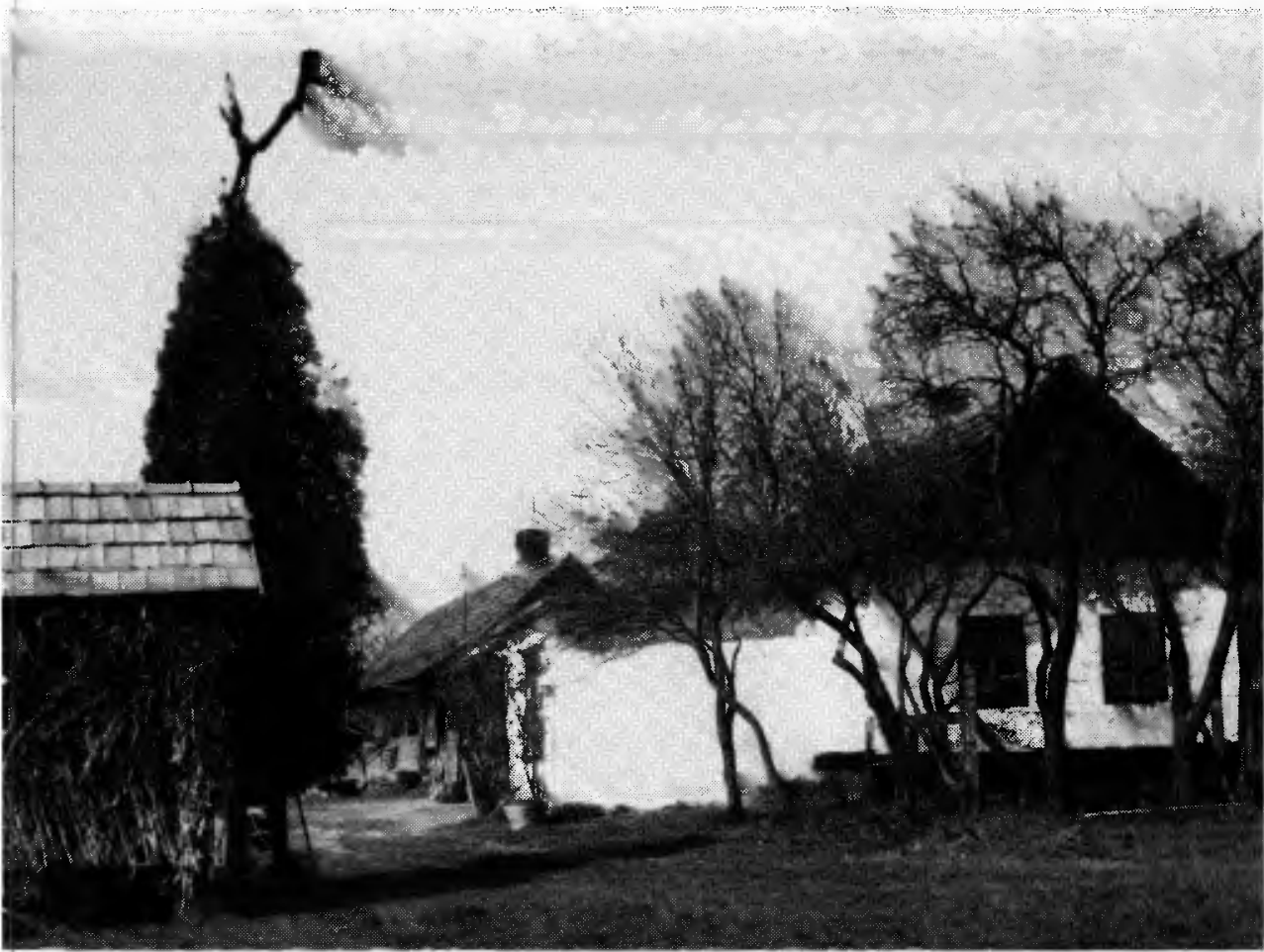




\title{
HAMAROSAN MEGJELENIK! TECHNOLÓGIAI PARKOK ÉS TECHNOPOLISZOK FÖLDRAJZA
}

\section{GEORGES BENKO}

A világ első technológiai parkja, amely Szilicium-völgy néven vált ismertté, az Egyesült Államok nyugati partján, San Francisco közelében fejlödött ki, az 1960-as években. A recept nem túl bonyolult: végy egy jóhírủ egyetemet (Stanford Egyetem) és csúcstechnológiát alkalmazó ipart (elekronikai ipar, félvezető-gyártás, számítógép ipar), keverd össze őket (kihasználva a kölcsönös érdeklödést és érdeket: a Stanford Egyetem 1951-ben létrehozta a Stanford Ipari Parkot, amelynek jövedelme azóta is gazdagítja az egyetemet és finanszírozza a K+F kutatásokat), fưszerezd bőven állami-katonai megrendelésekkel. A fogyasztást vonzó környezetben ajánljuk...

A Szilicium-völgy siker-sztorijára gyorsan felfigyeltek mind az iparfejlesztő, mind a terület-városfejlesztő szakemberek. A technológiai parkban megtestesülni látták az ideális környezetet az innovációk megszületésére és kibocsátására. Úgy gondoltảk, hogy technológiai parkok nemcsak a véletlenek kedvező összejátszása révén alakulhatnak ki, mint a Szilicium-völgyben, hanem ez a létesítmény mesterségesen is létrehozható. És megindult a technológiai parkok épitése szerte a feljett világban.

Mindamellett, hogy korunkban már a technológiai parkok gazdag hálózata alakult ki Észak-Amerikában, Japánban és Nyugat-Európában, és épitésük most is napirenden van, a technológiai parkok egy része nem váltotta be a hozzájuk fủzött reményeket. Valójában ma megoszlanak a vélemények a technológiai parkokról, és ezt a vitát, ahogy a könyv szerzője, Georges BENKO is írja, az idő fogja eldönteni. Néhány év, vagy évtized múltán fog kiderül, hogy a technológiai parkok hozzájárultak-e az új ipari terek kialakulásához, és hogy a mostani technopoliszok lesznek-e az újonnan formálódó ipari térstruktúra központjai.

\section{A TARTALOMBÓL:}

\author{
I. rész: NAPJAINK TÉRGAZDASÁGA ÉS A TECHNOLÓGIAI PARKOK \\ I. fejezet: Válságok, technológiák, politikai irányzatok \\ II. fejezet: Uj ipari terek kialakulása \\ II. rész: A VILÁG ÚJ IPARI TÉRSÉGEI \\ I. fejezet: Uj ipari térségek az Egyesült Allamokban \\ II. fejezet: Japán \\ III. fejezet: Az európai termelési terek különbözőségei \\ III. rész: A TECHNOLOGIAI PARKOK KÍSÉRŌ ELEMEI \\ I. fejezet: A technológiai parkok és a vállalati inkubátor-házak \\ II. fejezet: Uj technológiák és a vállalkozások finanszírozása
}

Georges Benko könyve december végén jelenik meg az RKK gondozásában. Megvásárolható, vagy megrendelhető az MTA RKK Budapesti Osztályán (rózsaszín postautalványon, postacím: 1014 Budapest, Országház u. 9.)

Ára: helyben megvásárolva $250 \mathrm{Ft}$

$$
\begin{aligned}
\text { Postán elküldve Budapestre } & +24 \mathrm{Ft}, \\
\text { Vidékre } & +36 \mathrm{Ft} \text { (posta költség) }
\end{aligned}
$$

